\title{
Evaluation of Enterprise Innovation Ability of College Students' Pioneer Park Based on factor Analysis Model
}

\author{
Boyu Yang \\ School of Economics, Shanghai University, Shanghai, China \\ 735253147@qq.com
}

Keywords: College Students' Innovation Park; Innovation ability evaluation; Factor analysis model

\begin{abstract}
The increasingly serious form of employment has given birth to the rapid development of College Students' pioneer parks, and the innovative ability of enterprises in the park has become the key factor for enterprises to survive and survive for a long time. Based on this, this paper uses the relevant data of 11 enterprises in Hangzhou, and uses the factor analysis model to evaluate the innovation ability of 134 enterprises. The results show that four factors, such as innovation environment factor, R \& D investment capability factor, marketing capability factor and human capital accumulation factor, are the key factors that affect the innovation capability of enterprises in the park. It is concluded that enterprises in the park should improve their technological innovation capability, especially to strengthen the R \& D investment and the accumulation of human capital and other related indicators.
\end{abstract}

\section{Introduction}

The entrepreneurial park of college students is the practice platform and important carrier to cultivate and improve the entrepreneurial ability of college students. In the current situation of increasing employment in colleges and universities, it is an important measure to transport talents and cultivate new employment growth points. The third is to meet the needs of students self-help [1], in recent years, Hangzhou City, the full use of existing resources to actively create a student business start-up; the other is to promote the integration of education and practice; Garden, in the guide resources to optimize the allocation of circumstances, driven by college students employment. Innovation ability is the most basic characteristic of college students' entrepreneurial enterprises, and it is also an important criterion to improve their competitiveness. This paper uses the data of Hangzhou Pioneer Park students to evaluate the innovation ability of enterprises and find out the key factors that affect the innovation ability of the park enterprises, and provide reference for the entrepreneurs and policy makers in colleges and universities.

\section{The Composition of the Enterprise's Innovation Ability and the Initial Evaluation Index System}

The innovation ability of the enterprise is a generalized concept. It should be the sum of the innovation ability of different factors within the same subject, such as the management innovation, the system innovation, the technological innovation and the organization innovation. The narrow sense of innovation, generally refers to the enterprise's technological innovation [2]. This article discusses the innovative ability refers to the enterprise's technological innovation ability, that is, the narrow sense of innovation.

SchaePetr (1926) argues that innovation is the introduction of a "new combination" of a factor of production and production that has never been used to create a system of innovation. A new production function [3]. However, Burgelman (1988) [4] argues that corporate technological innovation is a series of comprehensive features that facilitate the organization of enterprises to support technological innovation strategies. It includes the use of resources and distribution, understanding of the development of the industry, the understanding of technological development, strategic management capabilities, structure and cultural conditions. Larry E.Westphal (1981) [5] and other scholars believe that enterprise technology innovation ability is organizational capacity, 
adaptability, product development ability, improve production technology ability, reserve capacity synthesis. There is also a similar view of D.L.Barton (1992) [6], that the core of technological innovation is to master the professional knowledge of people, technical systems, management system capabilities and corporate values and corporate culture. These scholars from different angles on the enterprise's technological innovation ability to give their own decomposition, but did not assess the ability of enterprises to innovate.

Domestic research on the assessment of technological innovation capability is quite abundant. (2004) [7] According to the innovative chain model proposed by Kline and Rosenberg, from the accumulation of technology, $\mathrm{R} \& \mathrm{D}$ investment, the production of new technologies to digest, the ability to sell new products And so on four aspects selected 10 indicators, as the enterprise technology innovation ability evaluation index system, with the index method and the comprehensive index evaluation method to carry on the appraisal. Yang Hongjin (1998) [8] decomposed the structural elements of technological innovation capability into six aspects: innovation resource input ability, R \& D ability, manufacturing ability, marketing ability, innovation management ability and innovation output ability. According to the technological innovation process Characteristics, and use the "correlation analysis" method in the multivariate statistical analysis to discuss the evaluation of technological innovation capability. (School of Economics and Management, Nanjing University of Aeronautics and Astronautics, Nanjing 210009, China) This paper presents a factor analysis model for the measurement and evaluation of technological innovation capability of enterprises, and uses this model to explore the main influencing factors of technological innovation capability. Related enterprises conducted a comprehensive evaluation.

The decomposition and evaluation of the technological innovation ability of the above-mentioned scholars have great significance for the determination of the initial indicators. From the process of technological innovation, the process of technological innovation is a process from resource investment to $\mathrm{R} \& \mathrm{D}$, trial production, production and sales. Only by maximizing the efficiency of each process can the whole innovation process be maximized. The innovation ability of college students' entrepreneurial park enterprises also follow this law. Therefore, according to the process of product innovation, the final selection of 11 initial indicators.

Table 1 Initial index selection

\begin{tabular}{|c|c|c|}
\hline variable & Initial indicator & Indicator Explanation \\
\hline $\mathrm{X} 1$ & $\begin{array}{l}\text { The proportion of } \\
\text { undergraduates and above }\end{array}$ & $\begin{array}{l}\text { Number of undergraduates and above / total number } \\
\text { of employees }\end{array}$ \\
\hline $\mathrm{X} 2$ & $\begin{array}{l}\text { Innovative product sales } \\
\text { share }\end{array}$ & Sales of innovative products / total sales revenue \\
\hline $\mathrm{X} 3$ & $\begin{array}{l}\mathrm{R} \& \mathrm{D} \text { personnel put } \\
\text { strength }\end{array}$ & $\begin{array}{c}\text { Number of R \& D Staff / Total Number of } \\
\text { Employees }\end{array}$ \\
\hline $\mathrm{X} 4$ & $\mathrm{R} \& \mathrm{D}$ funding strength & $\mathrm{R} \& \mathrm{D}$ expenditure / total sales re venue \\
\hline $\mathrm{X} 5$ & Monthly sales revenue & Total sales revenue \\
\hline X6 & Number of patents & Number of patents applied \\
\hline $\mathrm{X} 7$ & $\begin{array}{l}\text { Project Matching Matching } \\
\text { Satisfaction }\end{array}$ & $\begin{array}{l}\text { Qualitative indicators, using scoring system, a total } \\
\text { of } 5 \text { points }\end{array}$ \\
\hline $\mathrm{X} 8$ & $\begin{array}{l}\text { Relevant advisory body } \\
\text { satisfaction }\end{array}$ & Qualitative indicators \\
\hline X9 & $\begin{array}{l}\text { Whether the company has } \\
\text { new products }\end{array}$ & $\begin{array}{c}\text { Dummy variable, } 1 \text { for new product; } 0 \text { for no new } \\
\text { product }\end{array}$ \\
\hline X10 & $\begin{array}{l}\text { Entrepreneurship Park } \\
\text { Location Satisfaction }\end{array}$ & $\begin{array}{l}\text { Qualitative indicators, scoring system, a total of } 5 \\
\text { points }\end{array}$ \\
\hline $\mathrm{X} 11$ & $\begin{array}{c}\text { Venture park hardware and } \\
\text { software facilities } \\
\text { satisfaction }\end{array}$ & $\begin{array}{l}\text { Qualitative indicators, scoring system, a total of } 5 \\
\text { points }\end{array}$ \\
\hline
\end{tabular}




\section{Data and Model Settings}

Data sources. The research group conducted a questionnaire survey on 134 enterprises of 11 college students' entrepreneurship parks in Hangzhou (located in Shangcheng District, Xiacheng District, Gongshu District, Xihu District, Gaoxin Zone, Xiaoshan District, Yuhang District, Fuyang, Lin'an, Xiasha Higher Education Zone, Saibo start workshop), the successful issue of 146 questionnaires, recycling 140 copies, of which 134 valid questionnaires. The recovery was $95.9 \%$ and the effective rate was $95.7 \%$. Industry categories related to sales, service, electronic information, new materials, cultural and creative, new energy and energy conservation, biological and new medicine, optoelectronic equipment eight categories.

Model settings. Let $\mathrm{X}=(\mathrm{X} 1, \mathrm{X} 2, \mathrm{X} 3, \ldots, \mathrm{Xp})$ for the $\mathrm{P}$ entrepreneurial park enterprise technology innovation evaluation index vector, And $\mathrm{E}(\mathrm{X})=0, \mathrm{COV}(\mathrm{X})=\Sigma$ is equal to the correlation matrix $\mathrm{R}$ (R-factor analysis). $\mathrm{F}=(\mathrm{F} 1, \mathrm{~F} 2, \mathrm{~F} 3, \ldots, \mathrm{Fm})(\mathrm{m}<\mathrm{P})$ is an observable vector, And $\mathrm{E}(\mathrm{F})=0, \mathrm{COV}(\mathrm{F})=\mathrm{I}$, the components of vector $\mathrm{F}$ are independent of each other. Have:

$\mathrm{X}_{1}=\mathrm{a}_{11} \mathrm{~F}_{1}+\mathrm{a}_{12} \mathrm{~F}_{2}+\mathrm{a}_{13} \mathrm{~F}_{2}+\ldots \mathrm{a}_{1 \mathrm{~m}} \mathrm{~F}_{\mathrm{m}}+\varepsilon_{1}$

$\mathrm{X}_{2}=\mathrm{a}_{21} \mathrm{~F}_{1}+\mathrm{a}_{22} \mathrm{~F}_{2}+\mathrm{a}_{23} \mathrm{~F}_{2}+\ldots \mathrm{a}_{2 \mathrm{~m}} \mathrm{~F}_{\mathrm{m}}+\varepsilon_{2}$

$\mathrm{X}_{\mathrm{p}}=\mathrm{a}_{\mathrm{p} 1} \mathrm{~F}_{1}+\mathrm{a}_{\mathrm{p} 2} \mathrm{~F}_{2}+\mathrm{a}_{\mathrm{p} 3} \mathrm{~F}_{2}+\ldots \mathrm{a}_{\mathrm{pm}} \mathrm{F}_{\mathrm{m}}+\varepsilon_{\mathrm{p}}$

The matrix form can be expressed as: $\mathrm{X}=\mathrm{AF}+\varepsilon$ Where $\varepsilon=(\varepsilon 1, \varepsilon 2, \ldots, \varepsilon p)$ is a special factor, And satisfies $\mathrm{E}(\varepsilon)=0, \operatorname{COV}(\mathrm{F}, \varepsilon)=0$

$$
A=\left[\begin{array}{ccc}
\mathrm{a}_{11} & \cdots & \mathrm{a}_{1 \mathrm{~m}} \\
\vdots & \ddots & \vdots \\
\mathrm{a}_{\mathrm{m} 1} & \cdots & \mathrm{a}_{\mathrm{mp}}
\end{array}\right]
$$

In this paper, the principal component method is used to solve the factor load. Let $\mathrm{X}=(\mathrm{X} 1, \mathrm{X} 2$, $\mathrm{X} 3, \ldots, \mathrm{Xp}$ ) covariance is $\Sigma$, The eigenvalues of $\Sigma$ and the corresponding standard orthogonalization eigenvectors are: $\lambda_{1} \geq \lambda_{2} \geq \ldots \geq \lambda_{\mathrm{p}} \geq 0 \quad ; \mathrm{e}_{1}, \mathrm{e}_{2}, \ldots \mathrm{e}_{\mathrm{p}} \quad$ so $\Sigma=\mathrm{U}\left[\begin{array}{ccc}\lambda_{1} & \cdots & 0 \\ \vdots & \ddots & \vdots \\ 0 & \cdots & \lambda_{\mathrm{p}}\end{array}\right] \mathrm{U}^{\prime}=\sum_{\mathrm{i}=1}^{\mathrm{p}} \lambda_{\mathrm{i}} \mathrm{e}_{\mathrm{i}} \mathrm{e}_{\mathrm{i}}^{\prime} \quad$ When the last $\mathrm{p}-\mathrm{m}$ eigenvalues are small, the covariance matrix can be decomposed into:

$$
\begin{gathered}
\Sigma \approx\left(\sqrt{\lambda_{1}} \mathrm{e}_{1}, \ldots, \sqrt{\lambda_{\mathrm{m}}} \mathrm{e}_{\mathrm{m}}\right)\left(\begin{array}{c}
\sqrt{\lambda_{1}} \mathrm{e}_{1}^{\prime} \\
\vdots \\
\sqrt{\lambda_{\mathrm{m}}} \mathrm{e}_{\mathrm{m}}^{\prime}
\end{array}\right)+\left(\begin{array}{ccc}
\sigma_{1}^{2} & & \\
& \ddots & \\
& \mathrm{AA}^{\prime}+\operatorname{diag}\left(\sigma_{1}^{2}, \sigma_{2}^{2}, \cdots, \sigma_{\mathrm{p}}^{2}\right)
\end{array}\right)=\mathrm{AA}^{\prime}+\Sigma_{\tau}
\end{gathered}
$$

In this paper, factorization is used to maximize the factorization. The purpose is to obtain the result that the absolute value of each column element of the load matrix can be polarized to 1 and 0 as much as possible. Taking the plane orthogonal rotation of two factors as an example to illustrate its principle. The orthogonal rotation must satisfy the maximum variance of the total variance $\mathrm{V} 1+$ $\mathrm{V} 2=$ max of the factor load array obtained after the rotation.

Set $A=\left(\begin{array}{cc}\mathrm{a} 11 & \mathrm{a} 12 \\ \vdots & \vdots \\ \operatorname{ap} 1 & \mathrm{ap} 2\end{array}\right) \quad \mathrm{C}=\left[\begin{array}{cc}\cos \emptyset & -\sin \emptyset \\ \sin \emptyset & \cos \emptyset\end{array}\right] \quad \mathrm{C}$ is an orthogonal matrix

$\mathrm{B}=\mathrm{AC}=\left(\begin{array}{cc}\mathrm{a} 11 \cos \emptyset+\mathrm{a} 12 \sin \emptyset & -\mathrm{a} 11 \sin \emptyset+\mathrm{a} 12 \cos \emptyset \\ \vdots & \vdots \\ \mathrm{ap} 1 \cos \emptyset+\mathrm{ap} 2 \sin \emptyset & -\mathrm{ap} 1 \sin \emptyset+\mathrm{ap} 2 \cos \emptyset\end{array}\right)=\left(\begin{array}{cc}\mathrm{b} 11 & \mathrm{~b} 12 \\ \vdots & \vdots \\ \mathrm{bp} 1 & \mathrm{bp} 2\end{array}\right)$

$\mathrm{V}_{\alpha}=\frac{1}{\mathrm{P}}\left(\sum_{\mathrm{i}=1}^{\mathrm{p}} \frac{\mathrm{b}_{\mathrm{i} \alpha}^{2}}{\mathrm{~h}_{\mathrm{i}}^{2}}\right)^{2}-\left(\frac{1}{\mathrm{p}} \sum_{\mathrm{i}=1}^{\mathrm{p}} \frac{\mathrm{b}_{\mathrm{i}}^{2}}{\mathrm{~h}_{\mathrm{i}}^{2}}\right)^{2} \quad \alpha=1,2$

$\mathrm{G}=\mathrm{V}_{1}+\mathrm{V}_{2}=\max$ and $\frac{\partial \mathrm{G}}{\partial \emptyset}=0$

The establishment of the common factor as the dependent variable, the original variable as an independent regression equation:

$\mathrm{F}_{\mathrm{j}}=\beta_{\mathrm{j} 1} \mathrm{X}_{1}+\beta_{\mathrm{j} 2} \mathrm{X}_{2}+\ldots+\beta_{\mathrm{jm}} \mathrm{X}_{\mathrm{m}}, \mathrm{j}=1,2, \ldots, \mathrm{m} \quad$ Where $\mathrm{F}$ and $\mathrm{M}$ are normalized vectors, $\beta_{\mathrm{jm}}$ can 
be estimated by the least squares method, and the estimated factor score coefficient and the value of the original variable can be scored by the above equation. To further combine the corresponding variance contribution rate, we can establish the following integrated linear evaluation function:

\section{Empirical analysis}

Determine the common factor. Determine the common factor, according to the main factor eigenvalue is greater than 1 standard, select the first four components as the main factor. Since the cumulative contribution of variance is considered to be the overall interpretation of the total data for these factors, we can see from the table that the cumulative variance contribution of the first four common factors is $77.34 \%$, indicating that the four principal factors Keep the original 11 indicators almost all the information.

Factor naming. It is difficult to clearly see the relationship between the variables and the load in the factor load matrix. The factor orthogonal rotation is carried out with the criterion of "variance maximization", and the factor load matrix after the variance is maximized is obtained. The factor matrix of the rotation after the rotation can change the load of each variable in each factor so that some variables have a higher load on a certain factor. According to the post-rotation factor load matrix, we can get the main public factor with clear economic significance, as shown in the table.

Table 2 Table of factor loading matrix after rotation

\begin{tabular}{|l|c|c|c|c|}
\hline & \multicolumn{4}{|c|}{ Component } \\
\cline { 2 - 5 } & $\mathrm{F} 1$ & $\mathrm{~F} 2$ & $\mathrm{~F} 3$ & $\mathrm{~F} 4$ \\
\hline $\mathrm{X} 1$ & -.079 & .035 & -.046 & .971 \\
$\mathrm{X} 2$ & -.028 & .856 & .031 & .134 \\
$\mathrm{X} 3$ & .034 & .859 & -.042 & .005 \\
$\mathrm{X} 4$ & -.052 & .627 & -.350 & -.203 \\
$\mathrm{X} 5$ & .195 & -.058 & .869 & -.053 \\
$\mathrm{X} 6$ & .169 & .560 & .533 & -.027 \\
$\mathrm{X} 7$ & .890 & .031 & .025 & -.025 \\
$\mathrm{X} 8$ & .892 & .022 & .072 & .125 \\
$\mathrm{X} 9$ & .057 & .894 & .116 & .037 \\
$\mathrm{X} 10$ & .877 & .053 & .075 & -.107 \\
$\mathrm{X} 11$ & .920 & -.017 & .066 & -.061 \\
\hline
\end{tabular}

According to the post-rotation factor load matrix table, on the $\mathrm{F} 1$, the $\mathrm{X} 7$ project matches the satisfaction degree, the satisfaction degree of the X8 related consulting institution, the satisfaction of these factors, so that the load of these factors is relatively large. We will be the main factor named college students entrepreneurial park innovation environment factors, reflecting the enterprise innovation environment on the impact of enterprise innovation.

Table3 Factor score matrix

\begin{tabular}{|l|c|c|c|c|}
\hline & \multicolumn{4}{|c|}{ Component } \\
\cline { 2 - 5 } & $\mathrm{F} 1$ & $\mathrm{~F} 2$ & $\mathrm{~F} 3$ & $\mathrm{~F} 4$ \\
\hline $\mathrm{X} 1$ & -.033 & .039 & .002 & .936 \\
$\mathrm{X} 2$ & .085 & .278 & .002 & .105 \\
$\mathrm{X} 3$ & .098 & .270 & -.080 & -.015 \\
$\mathrm{X} 4$ & .035 & .207 & -.338 & -.211 \\
$\mathrm{X} 5$ & .099 & -.057 & .747 & -.051 \\
$\mathrm{X} 6$ & .137 & .148 & .424 & -.039 \\
$\mathrm{X} 7$ & .235 & -.105 & -.157 & .035 \\
$\mathrm{X} 8$ & .235 & -.106 & -.110 & .180 \\
$\mathrm{X} 9$ & .118 & .276 & .057 & .014 \\
$\mathrm{X} 10$ & .238 & -.099 & -.112 & -.047 \\
$\mathrm{X} 11$ & .241 & -.125 & -.124 & .003 \\
\hline
\end{tabular}

The score of each principal factor is calculated according to the factorization coefficient matrix and the normalized value of the original index. The main factor score is as follows: 


$$
\begin{aligned}
& \mathrm{F}_{1}=-0.033 \mathrm{X}_{1}+0.085 \mathrm{X}_{2}+0.098 \mathrm{X}_{3}+\ldots+0.238 \mathrm{X}_{10}+0.241 \mathrm{X}_{11} \\
& \mathrm{~F}_{2}=0.039 \mathrm{X}_{1}+0.278 \mathrm{X}_{2}+0.270 \mathrm{X}_{3}+\ldots-0.099 \mathrm{X}_{10}-0.125 \mathrm{X}_{11} \\
& \mathrm{~F}_{3}=0.002 \mathrm{X}_{1}+0.002 \mathrm{X}_{2}-0.080 \mathrm{X}_{3}-\ldots-0.112 \mathrm{X}_{10}-0.124 \mathrm{X}_{11} \\
& \mathrm{~F}_{4}=0.936 \mathrm{X}_{1}+0.105 \mathrm{X}_{2}-0.015 \mathrm{X}_{3}-\ldots-0.047 \mathrm{X}_{10}+0.003 \mathrm{X}_{11}
\end{aligned}
$$

And further combined with the corresponding variance contribution rate, according to the evaluation function and the enterprise main factor score, calculate the enterprise innovation ability comprehensive score: $\mathrm{F}=31.73 \% * \mathrm{~F}_{1}+26.45 \% * \mathrm{~F}_{2}+9.81 \% * \mathrm{~F}_{3}+9.35 \% * \mathrm{~F}_{4} \quad$ The overall score and ranking of the innovation capacity of each park are as follows:

\section{Conclusion}

From the integrative factor score and ranking business park, Zhejiang University Science Park Based on the rich resources of the high innovation ability of the list, but also from the side of the transformation of College Business Park cannot do without scientific and technological achievements in universities. Yuhang, Xiaoshan, the lower city and other pioneering parks also have a good foundation for development, so that their ability to innovate in the middle of the upstream. Ling'an, high-tech, Fuyang, three innovative capacity is far less than the previous Pioneer Park, should be vigilant. And from innovation environment factors, R \& D investment ability factor, market sales ability factor and human capital accumulation factor four factors, strengthen R \& D investment, human capital accumulation and other measures.

\section{References}

[1] Lanhua, Yang Honglou. Current situation and countermeasures of college students' entrepreneurial park construction. Education and occupation [J], 2016 (10): 74-75.

[2] Wei Jiang, Guo Bin. Enterprise technical ability and technological innovation ability evaluation index system [J]. China high-tech enterprise evaluation, 1995 (06): 29-34.

[3] Guo Guofeng, Wen Junwei, Sun Baoying. Analysis of influencing factors of technological innovation capability - empirical study based on panel data of six provinces in central China [J]. Journal of Quantitative Economics and Technology, 2007 (09): 134-136.

[4] R.A.Burgelman. Toward an innovative capabilities audit framework. Research paper (Stanford University. Graduate School of Business), 1988: 27-28.

[5] Larry E. Westphal, Yung W. Rhee and Garry Pursell, Sources of Technological Capability in South Area, Technologi-cal Capability in the ThirdWorld, Edited by M. Fransman and K. King, 1984: (163-279).

[6] Barton D L. Core capability \& core rigidities: A paradox in managingnew product development. Strategic Mgt J, 1992,(13):62-64.

[7] Dai Dongxiu, Li Rui, Song Huimin. Technology of Technology Innovation Evaluation Index System Based on Chain Model [J]. Progress and Countermeasures, 2004 (6): 78-79.

[8] Yang Hongjin. Empirical Analysis of Evaluation Indexes of Enterprise Technology Innovation Capability [J]. Journal of Statistical Research, 1998, V15 (1): 53-58.

[9] Bai Junhong, Jiang Keshen, Li Jing, Lin Leifang. Factor analysis model of enterprise technology innovation capability measurement and evaluation and its application [J]. China Soft Science, 2008 (3): 108-109. 